University of Nebraska - Lincoln

DigitalCommons@University of Nebraska - Lincoln

Agronomy \& Horticulture - Faculty Publications

Agronomy and Horticulture Department

2012

Identification and Characterization of Four Missense Mutations in Brown midrib 12 (Bmr12), the Caffeic O-Methyltranferase (COMT) of Sorghum

\author{
Scott E. Sattler \\ USDA-ARS, Scott.Sattler@ars.usda.gov \\ Nathan A. Palmer \\ USDA-ARS, nathan.palmer@ars.usda.gov \\ Ana Saballos \\ University of Florida \\ Ann M. Greene \\ University of Florida \\ Zhanguo Xin \\ USDA-ARS \\ Follow this and additional works at: https://digitalcommons.unl.edu/agronomyfacpub \\ a next page for additional authors \\ Part of the Agricultural Science Commons, Agriculture Commons, Agronomy and Crop Sciences \\ Commons, Botany Commons, Horticulture Commons, Other Plant Sciences Commons, and the Plant \\ Biology Commons
}

Sattler, Scott E.; Palmer, Nathan A.; Saballos, Ana; Greene, Ann M.; Xin, Zhanguo; Sarath, Gautam; Vermerris, Wilfred; and Pedersen, Jeffrey F., "Identification and Characterization of Four Missense Mutations in Brown midrib 12 (Bmr12), the Caffeic O-Methyltranferase (COMT) of Sorghum" (2012). Agronomy \& Horticulture -- Faculty Publications. 690.

https://digitalcommons.unl.edu/agronomyfacpub/690

This Article is brought to you for free and open access by the Agronomy and Horticulture Department at DigitalCommons@University of Nebraska - Lincoln. It has been accepted for inclusion in Agronomy \& Horticulture -Faculty Publications by an authorized administrator of DigitalCommons@University of Nebraska - Lincoln. 


\section{Authors}

Scott E. Sattler, Nathan A. Palmer, Ana Saballos, Ann M. Greene, Zhanguo Xin, Gautam Sarath, Wilfred Vermerris, and Jeffrey F. Pedersen 


\title{
Identification and Characterization of Four Missense Mutations in Brown midrib 12 (Bmr12), the Caffeic $O$-Methyltranferase (COMT) of Sorghum
}

\author{
Scott E. Sattler • Nathan A. Palmer • Ana Saballos • \\ Ann M. Greene • Zhanguo Xin • Gautam Sarath • \\ Wilfred Vermerris • Jeffrey F. Pedersen
}

Published online: 22 April 2012

(C) Springer Science+Business Media, LLC (outside the USA) 2012

This article is a U.S. government work, and is not subject to copyright in the United States.

\begin{abstract}
Modifying lignin content and composition are targets to improve bioenergy crops for cellulosic conversion to biofuels. In sorghum and other $\mathrm{C} 4$ grasses, the brown midrib mutants have been shown to reduce lignin content and alter its

The U.S. Department of Agriculture (USDA) prohibits discrimination in all its programs and activities on the basis of race, color, national origin, age, disability, and where applicable, sex, marital status, familial status, parental status, religion, sexual orientation, genetic information, political beliefs, reprisal, or because all or part of an individual's income is derived from any public assistance program (not all prohibited bases apply to all programs). Persons with disabilities who require alternative means for communication of program information (Braille, large print, audiotape, etc.) should contact USDA's TARGET Center at (202) 720-2600 (voice and TDD). To file a complaint of discrimination, write to USDA, Director, Office of Civil Rights, 1400 Independence Avenue, S.W., Washington, D.C. 20250-9410, or call (800) 795-3272 (voice) or (202) 720-6382 (TDD). USDA is an equal opportunity provider and employer. Mention of trade names or commercial products in this publication is solely for the purpose of providing specific information and does not imply recommendation or endorsement by the U.S. Department of Agriculture.
\end{abstract}

Electronic supplementary material The online version of this article (doi:10.1007/s12155-012-9197-z) contains supplementary material, which is available to authorized users.

S. E. Sattler $(\bowtie) \cdot$ N. A. Palmer $\cdot$ G. Sarath $\cdot$ J. F. Pedersen Grain Forage and Bioenergy Research Unit, USDA-ARS,

Lincoln, NE 68583, USA

e-mail: Scott.Sattler@ars.usda.gov

S. E. Sattler $\cdot$ N. A. Palmer $\cdot$ G. Sarath $\cdot$ J. F. Pedersen

Department of Agronomy and Horticulture,

University of Nebraska-Lincoln,

Lincoln, NE 68583, USA

A. Saballos $\cdot$ A. M. Greene $\cdot$ W. Vermerris

Agronomy Department and Genetics Institute,

University of Florida,

Gainesville, FL 32610, USA

Z. Xin

Plant Stress and Germplasm Development Unit, USDA-ARS, Lubbock, TX 79415, USA composition. Bmrl2 encodes the sorghum caffeic $O$-methyltransferase, which catalyzes the penultimate step in monolignol biosynthesis. From an EMS-mutagenized TILLING population, four $b m r 12$ mutants were isolated. DNA sequencing identified the four missense mutations in the Bmr 12 coding region, which changed evolutionarily conserved amino acids Ala71Val, Pro150Leu, Gly225Asp, and Gly325Ser. The previously characterized bmr 12 mutants all contain premature stop codons. These newly identified mutants, along with the previously characterized bmr12-ref, represent the first allelic series of bmr 12 mutants available in the same genetic background. The impacts of these newly identified mutations on protein accumulation, enzyme activity, Klason lignin content, lignin subunit composition, and saccharification yield were determined. Gly225Asp mutant greatly reduced protein accumulation, and Pro150Leu and Gly325Ser greatly impaired enzyme activity compared to wild type (WT). All four mutants significantly reduced Klason lignin content and altered lignin composition resulting in a significantly reduced $\mathrm{S} / \mathrm{G}$ ratio relative to $\mathrm{WT}$, but the overall impact of these mutations was less severe than bmr12-ref. Except for Gly325Ser, which is a hypomorphic mutant, all mutants increased the saccharification yield relative to WT. These mutants represent new tools to decrease lignin content and $\mathrm{S} / \mathrm{G}$ ratio, possibly leading toward the ability to tailor lignin content and composition in the bioenergy grass sorghum.

Keywords Brown midrib · bmr12 · Caffeic $O$-methyltransferase $(\mathrm{COMT}) \cdot$ Lignin $\cdot$ Sorghum

\section{Introduction}

Photosynthetic carbon fixation is a key global consumer of atmospheric carbon dioxide, and the world community has 
started to look toward plant-based sustainable fuels and chemicals, which would mitigate carbon dioxide emission and reduce petroleum dependence [1, 2]. Lignocellulosic bioenergy conversion requires decomposition of the cell wall polysaccharides cellulose and hemicellulose into monomeric sugars. Lignin, the third cell wall component, is an ubiquitous polymer whose abundance in the world is exceeded only by cellulose [3]. It accounts for approximately $30 \%$ of organic carbon in the biosphere [4]. Lignin subunits are derived from the amino acid phenylalanine, hence both phenylalanine metabolism and lignin biosynthesis occupy central roles in plant metabolism. Lignin is polymerized from monolignols ( $p$-coumaryl, coniferyl, sinapyl alcohols) which form $p$-hydroxyphenol $(\mathrm{H})$, guaiacyl $(\mathrm{G})$, and syringyl (S) subunits in the lignin, respectively [4]. The lignin polymer cross-links these polysaccharides, rigidifying and reinforcing the secondary cell wall structure [4], resulting in a barrier that is chemically and microbially resistant. Reducing lignin has also become an important target for bioenergy feedstock improvement [5-7]. Although lignin makes liberating sugars from biomass more difficult, lignin also serves critical functions for vascular plants. Lignin is required for vascular elements to transport water under negative pressure, and in severely lignin deficient plants, vascular collapse has been observed [8-10]. Therefore, there is a limit to the extent to which lignin may be manipulated without significantly impacting plant fitness.

In the $\mathrm{C} 4$ grasses maize [Zea mays L.], sorghum, and pearl millet [Pennisetum glaucum (L.) Leek], the visible brown midrib phenotype has been useful for identifying mutants impaired in lignin synthesis (reviewed in [11]). In maize, there are at least six brown midrib (bm1-6) loci [12], and in sorghum, there are at least four brown midrib (bmr2, $6,12,19)$ loci [13]. Both the maize $B m 3$ and the sorghum Bmr12 loci encode orthologous caffeic $O$-methyltransferases (COMT) [14, 15], which catalyze the penultimate step in monolignol biosynthesis, the transfer of a methyl group from $S$-adenosyl-methionine (SAM) to the 5hydroxyl group of 5-hydroxyconiferyl aldehyde to form sinapyl aldehyde. bmr12-ref contains a premature stop prior to the sequence encoding the SAM domain [15], and the Bmr12 protein was undetectable in bmr12-ref plant extracts [16]. Together these results indicate that bmr12-ref is likely a null allele. bmr12-ref plants had significantly altered lignin composition and had a significantly reduced amount of lignin compared to their wild type (WT) near isogenic parents in multiple grain and forage sorghum varieties $[6,13,15-18]$. The reduction in lignin deposition was also observed at the cellular level through histochemically stained internode sections and light microscopy. bmr12-ref showed reduced lignin staining and altered cell morphology relative to WT, but vascular collapse was not observed in bmr12-ref [16], indicating that the structural role of lignin was still maintained. In addition, sorghum lines carrying bmr12-ref mutation had significantly increased ethanol conversion efficiency of lignocellulosic tissues relative to WT tissues using standard dilute acid pretreatment and hydrolytic enzymes [6, 13], which supports targeting this locus to improve sorghum biomass for conversion.

The previously characterized bmr 12 mutants: bmr12-ref, bmr12-18, bmr12-25, and bmr12-26 all contain premature stop codons [13, 15, 19]. Hypomorphic alleles of bmr12 would potentially retain residual function, which may be useful to modulate enzymatic activity and fine tune biomass composition. Here we characterize the effects of four EMSderived bmr 12 alleles have on gene expression, COMT enzymatic activity, lignin content and composition, and stover saccharification in the same genetic background B Tx623. These findings make some of the bmr12 alleles characterized in this article promising tools to tailor lignin content and composition in sorghum for cellulosic bioenergy uses.

\section{Materials and Methods}

\section{Preparation of Plant Materials}

The near isogenic bmr12-ref genetic stock was developed by crossing the brown midrib sources F220 or F324 (bmr12-ref, a gift from Robert Kalton) to the recurrent parent B Tx623 and followed by three to four backcross cycles as described previously [20]. The other bmr 12 alleles were isolated from an EMS-mutagenized TILLING population (B Tx623) based on visible brown midrib phenotype $[21,22]$. These lines were self-pollinated for at least two generations, but were not backcrossed to B Tx623. Allelism to $b m r 12$ was determined by complementation testing; bmr 12 missense alleles herein described failed to complement bmr12-ref. Seeds were sown in a soil mix consisting of soil to peat moss to vermiculite to perlite to sand (4:1:1:1:1), grown in $28-\mathrm{cm}$ pots under a 16 -h daylight regimen supplemented with high-pressure sodium lights and fertilized as needed (approximately every 7 days, $5 \mathrm{~mL}$ per pot) with a fertilizer containing 11:15:11 ( $\mathrm{N}$ to $\mathrm{P}$ to $\mathrm{K}$; Ferti-lome Gardener's Special). Plants were grown in the greenhouse during November 2009 and January 2012; temperatures were maintained at 29 to $30{ }^{\circ} \mathrm{C}$ during the day and 26 to $27{ }^{\circ} \mathrm{C}$ during the night. Upon seedling emergence, the plants were thinned to two plants per pot. The stalks were harvested with the leaf tissue removed approximately 5 to 6 weeks after planting for immunodetection and RT-qPCR.

Alternatively, plants were grown to full maturity in 2009 and 2010 at the University of Nebraska Field Laboratory, 
Ithaca, NE (Sharpsburg silty clay loam; fine, smectitic, mesic Typic Argiudoll). Nitrogen fertilizer was applied prior to planting at $157 \mathrm{~kg} \mathrm{ha}^{-1}$ both years. Individual plots consisted of two 7.6-m rows spaced $76 \mathrm{~cm}$ apart. Plots were seeded with a precision vacuum planter calibrated to deliver 240 seeds per plot. Material was planted on 21 May 2009 and 25 May 2010. In 2009, $3.8 \mathrm{~cm}$ of supplemental irrigation was applied via overhead sprinklers on 6 August and on 29 August. In 2010, $3.8 \mathrm{~cm}$ of supplemental irrigation was applied on 9 August. Days to flowering were recorded at $50 \%$ anthesis. Height was measured to the top of the mature panicle before harvest. The lignocellulosic tissues were harvested 7 October 2009 and 4 October 2010. Three individual plants were harvested at random from the center row of each block. Panicles were removed at maturity, and lignocellulosic tissue was harvested using a commercial silage cutter modified for small plot use and dried at $50{ }^{\circ} \mathrm{C}$ for further analysis. These materials were used for thioacidolysis, Klason lignin, and saccharification analyses.

\section{RNA Expression Analysis}

RNA was extracted from 5-week-old greenhouse-grown plant stalks as previously described [23]. One microgram of DNase-treated total RNA from each sample was reverse transcribed using a Transcriptor First Strand cDNA kit (Roche Diagnostics, Indianapolis, IN) for real-time PCR. Three biological replicates were analyzed for each mutant and WT. Real-time PCR was performed using Quantitect ${ }^{\circledR}$ SYBR Green (Qiagen, Valencia, CA) and an Eppendorf Mastercycler EP Realplex PCR module (Hamburg, Germany). Primers for Bmr12 (Sb07g003860.1), and $\alpha$-tubulin (Sb01g009570.1) were designed using Invitrogen Vector NTI software (Life Technologies Corporation, Grand Island, NY), and were 5'-GCTCACCCCTAACGA GGACGG-3' (forward), 5'-GCACCGCGTCCTTCAG GTAGTA-3' (reverse), and 5'-TCGGAAACGCGTGCTG GGAG-3' (forward), 5'-AGCATCGTCACCTCCCCCAA$3^{\prime}$ (reverse), respectively. Thermal cycling parameters consisted of a $15-\mathrm{min}$ hold at $95{ }^{\circ} \mathrm{C}$ to activate the enzyme, followed by 40 cycles of denaturing at $94{ }^{\circ} \mathrm{C}$ for $15 \mathrm{~s}$, annealing at $55{ }^{\circ} \mathrm{C}$ for $30 \mathrm{~s}$, and extension at $72{ }^{\circ} \mathrm{C}$ for $30 \mathrm{~s}$. Relative expression of mRNA was calculated using the $\Delta \Delta C_{\mathrm{t}}$ method. The values for Bmr12 were determined by normalizing their $C_{\mathrm{t}}$ values to $\alpha$-tubulin, a housekeeping gene. Controls containing RNA without reverse transcription and no template were performed to validate the detection and ensure the absence of DNA contamination within the RNA samples. Sample efficiencies and thresholds were determined by LinRegPCR software (http://www.hartfaalcentrum.nl/ index.php?main=files\&sub=LinRegPCR).
Western Blotting and Immunodetection

Immunodetection of Bmr12 followed our previous report [16] with some minor modifications. Proteins were extracted in protein extraction buffer containing $1 \%$ protease inhibitor (Sigma; P9599) from tissue ground in liquid nitrogen. Protein extracts were separated on a $12 \%$ SDS Bio-Rad criterion XT precast gel. Proteins were transferred to nitrocellulose membrane in a wet blot system for $45 \mathrm{~min}$ at $65 \mathrm{~V}$ in $10 \mathrm{mM}$ Tris, $100 \mathrm{mM}$ glycine, and $8 \%(v / v)$ methanol. Following transfer, the membrane was stained with Ponceau S stain to verify the quality of transfer and then blocked with $3 \%$ nonfat dry milk in TBST (TBS+ $0.5 \%$ Tween 20) for $1 \mathrm{~h}$. The membrane was probed with the primary antibody (polyclonal rabbit antisera against Bmr12 and polyclonal rabbit antisera against ascorbate peroxidase, a loading control) diluted 1:5,000 for $1 \mathrm{~h}$ followed by three washes with TBST for $5 \mathrm{~min}$ each. The secondary antibody (goat antirabbit IgG + horseradish peroxidase; Sigma-Aldrich A-0545) was diluted 1:10,000 and incubated for $1 \mathrm{~h}$. The membrane was washed in TBST for 5 min twice and then washed in $\mathrm{TBS}+0.5 \mathrm{M} \mathrm{NaCl}$ for $5 \mathrm{~min}$. Secondary antibody was detected through chemiluminescence using Amersham ECL western blotting reagent (GE Healthcare). Each lane of the gel represents one individual plant. The immunoblotting was performed on at least three different plants. We displayed representative blots from all analyzed blots.

\section{Bmr12 Recombinant Proteins}

The coding region of Bmr12 was PCR amplified and cloned into the pET30a vector as previously described [24]. The corresponding missense mutations described within this article were created in the expressed Bmr12 coding region through site-directed mutagenesis using the QuikChange Site-Directed Mutagenesis Kit and following the manufacturer's protocol (Stratagene, now Agilent). The presence of these point mutations was confirmed by automated DNA sequencing. Vectors were introduced into Rossetta R2 Escherichia coli cells for protein expression. Cultures were grown to log phase from a single colony at $37^{\circ} \mathrm{C}$, and then protein expression was induced using $0.1 \mathrm{mM}$ isopropylthio $\beta$ galactoside at $20{ }^{\circ} \mathrm{C}$ for approximately $18 \mathrm{~h}$. Soluble protein was extracted using sonication at $20 \mathrm{~W}$ with a 10 -s pulse following a 30 -s rest interval for $3 \mathrm{~min}$. The expressed protein, which contained N-terminal 6 His tag, was isolated by affinity purification on a nickel column and eluted with imidazole. Induction of the expressed protein and protein purification was monitored by SDS-PAGE. 
Enzyme Assays

COMT enzymatic activity was quantified using a continuous coupled fluorescent assay previously developed and validated [24]. S-Adenosyl homocysteine hydrolase (SAHH) was used as a coupling enzyme and the thiolspecific fluorophore, Thioglo1 (Covalent Associates Inc., Corvallis, OR), as detection reagent to monitor the conversion of the methyl donor SAM to a fluorescent product [24]. The reaction conditions were $100 \mathrm{mM}$ Tris buffer $\mathrm{pH} 7.5$, $1 \mu \mathrm{M}$ SAHH, $85 \mu \mathrm{M}$ SAM, $15 \mu \mathrm{M}$ Thioglo1, and $40 \mu \mathrm{M}$ 3,4-dihydroxy-5-methoxybenzaldehyde at $37^{\circ} \mathrm{C}$. The concentrations of the recombinant Bmr12 proteins were determined using a colorimetric assay (Pierce $660 \mathrm{~nm}$ Protein Assay; Pierce Biotechnology, Rockford, IL), and bovine serum albumin was used as a protein standard. Neither the maleimido form nor the hydrolyzed unconjugated Thioglo1 exhibits intrinsic fluorescence (http:// www.covalentassociates.com/thioglo.htm). Assays were performed in a black 96-well microtiter plate (Micro Fluor 2 black, flat well; ThermoFisher Scientific, Waltham, MA) using a Bio Tek Synergy HT fluorescence plate reader (Bio Tek Instruments, Winooski, VT). Fluorescence was monitored using an excitation filter $360 \pm 40 \mathrm{~nm}$ and an emission filter $528 \pm 20 \mathrm{~nm}$. Fluorescence signal was measured every minute for 45 min with an instrument predesignated "moderate shake" for $5 \mathrm{~s}$ between each read. Raw fluorescence data were imported into Microsoft Excel (MS Office 2007) and analyzed. Fluorescence data were converted into picomoles of $-\mathrm{SH}$ groups released based on a standard curve constructed using glutathione.

\section{Relative Lignin Composition}

Thioacidolysis followed by GC-MS was used to determine the relative lignin composition, and the $\mathrm{H}, \mathrm{G}$, and $\mathrm{S}$ subunits were identified with other minor lignin components based on mass spectra, and quantified using major ions $(\mathrm{m} / \mathrm{z})$ as previously published [16]. The ground lignocellulosic material (Wiley mill, 1-mm screen) was washed, extracted, derivatized, and analyzed as previously described [16]. Two hundred microliters of $1.25 \mathrm{mg} / \mathrm{mL}$ docosane in dichloromethane was added as an internal standard at the time of tissue extraction as previously described [16]. Lignin components were measured based on the peak area of major ions $(\mathrm{m} / \mathrm{z})$ as follows: H ligin 239, G lignin 269, S lignin 299, and hG lignin 357 as previously described [16]. The peak area of the internal standard docosane $(\mathrm{m} / z$ 57) was used for the normalization of peak areas between samples as previously described [16]. Analysis was performed on four biological individuals representing one individual from each block.
DNA Sequencing and Sequence Analysis

Eurofins MWG Operon (Huntsville, AL) performed automated DNA sequencing of amplification products. DNA sequence assembly and bioinformatic analysis were performed using the MacVector version 12.0 software package (Cary, NC).

\section{Klason Lignin Analysis}

Stover was dried and ground in a Wiley mill to pass a 1-mm screen, then extracted in warm $\left(60^{\circ} \mathrm{C}\right) 50 \%(v / v)$ ethanol for $45 \mathrm{~min}$ to remove soluble sugars, minerals, and soluble phenolics and dried at $50{ }^{\circ} \mathrm{C}$. One hundred-milligram extractive-free sorghum stover was used to determine the Klason lignin concentration. Klason lignin is defined as the ash-corrected residue remaining after the cell wall polysaccharides have been removed via a two-stage hydrolysis in concentrated $(12 \mathrm{M})$ and dilute $(0.4 \mathrm{M})$ sulfuric acid. The procedure was based on the method described by Theander and Westerlund [25], with the modifications of Hatfield et al. [26]. Means were calculated based on a minimum of nine plants, sampled from a randomized complete block design with four replicates with a least one plant from each replicate.

\section{Pretreatment and Enzymatic Saccharification}

Dilute sulfuric acid pretreatment was performed by autoclaving $300 \mathrm{mg}$ extractive-free stover at a $10 \%$ solids loading in $1.3 \%(w / v)$ sulfuric acid for $40 \mathrm{~min}$ at $121{ }^{\circ} \mathrm{C}$, as described in [13]. The residue was collected on a Whatman GF/A filter, washed in $50 \mathrm{~mL}$ deionized water $\left(65^{\circ} \mathrm{C}\right)$, and transferred to a $15-\mathrm{mL}$ tube. Enzymatic saccharification was carried out by adding a volume of $9.7 \mathrm{~mL}$ enzyme cocktail containing a 1:1 mix of Trichoderma reesei cellulase and Novozyme 188 (both from Sigma-Aldrich, St. Louis, MO) in $50 \mathrm{mM}$ sodium citrate buffer $\mathrm{pH} 4.8$ to $300 \mathrm{mg}$ of extractive-free unpretreated stover or to the filtrate remaining after pretreatment. Novozyme 188 is a $\beta$-glucosidase (cellobiase) enzyme preparation from Aspergillus niger that results in the hydrolysis of cellobiose to glucose. The enzyme cocktail had a cellulase activity of 60 FPU/g cellulose based on NREL standard activity measurement LAP006 [27], and the cellobiase activity in the cocktail was 2.0 CBU/mL (based on information from SigmaAldrich). The cocktail also contained tetracycline at a final concentration of $20 \mu \mathrm{g} / \mathrm{mL}$ to prevent microbial growth. The tubes containing the saccharification reactions were incubated at $50{ }^{\circ} \mathrm{C}$ in a shaker incubator shaking at $100 \mathrm{rpm}$. Hydrolysate samples $(100 \mu \mathrm{L})$ were collected at 4,20 , and $96 \mathrm{~h}$ (unpretreated stover) or $24 \mathrm{~h}$ (pretreated stover), placed in boiling water to inactivate the enzymes, cooled, 
centrifuged, and used to determined the glucose concentration using a calibrated OneTouch UltraSmart blood glucose meter (Roche Diagnostics, Indianapolis, IN) according to the procedure described in [7]. Means were calculated based on a minimum of nine plants, sampled from a randomized complete block design with four replicates with at least one plant from each block.

Statistical Analysis

Fisher's protected least significant difference (LSD) test was used to determine if there were statistically significant differences in Klason lignin content and glucose yields between genotypes. Pairwise comparisons among genotypes were made using Tukey's honest significant difference (HSD) with an experiment-wise error rate of $\alpha=0.05$ using the statistical software package SAS (Cary, NC). For the other datasets, the data were analyzed using SAS (Cary, NC) PROC MIXED v. 9.2 (SAS, 2002-2008). Heterogeneous variances were detected using Levene's test for homogeneity of variance and accounted for using PROC MIXED. $F$-protected least significant differences were used to determine differences among genotypes, which were considered significant at $P 0.05$ (SAS, 2002-2008).

\section{Results}

\section{Mutation Identification}

From an ethyl methane sulfonate (EMS)-mutagenized sorghum population [22], four brown midrib mutants (bmr12-30, bmr12-34, bmr12-35, and bmr12-820) were isolated for their characteristic tan to brown-colored midribs in contrast to green midrib found in WT B Tx623 sorghum lines. Their allelism to brown midrib 12 (bmr12) was confirmed through complement testing to plants carrying the bmr12-ref reference allele [15]. In the field, bmr12-30, bmr12-34, and bmr12-820 flowered significantly later than WT, bmr12-ref, or bmr12-35 (Supplementary Table 1). At maturity, the plant heights of all the bmr12 mutants were significantly shorter than WT, and bmr12-30 was shorter than other bmr12 mutants (Supplementary Table 1). The delayed flowering relative to WT or bmr12-ref for some bmrl 12 mutants suggests that these mutants may harbor effects of additional mutations from the generation of the TILLING population.

The DNA lesions responsible for the bmrl2 phenotype were identified through PCR amplification and DNA sequencing the Bmr12, the sorghum COMT (Sb07g003860.1) gene from these mutants and compared to WT B Tx623 [28]. Four transition ( $\mathrm{G}$ to $\mathrm{A}$ or $\mathrm{C}$ to $\mathrm{T}$ ) mutations were identified within the coding region of the gene, which was consistent
Table 1 Mutations identified in the Bmrl2 gene and their corresponding amino acid changes

\begin{tabular}{lll}
\hline bmr12 mutant & Mutation (position) & Amino acid change \\
\hline bmr12-30 & G2364A & Gly225Asp \\
bmr12-34 & C518T & Ala71Val \\
& C2139T & Pro150Leu \\
bmr12-820 & C518T & Ala71Val \\
& C2139T & Pro150Leu \\
$b m r 12-35$ & G2663A & Gly325Ser
\end{tabular}

Positions are based on sorghum COMT gene (Bmr12; Sb07g003860.1), Genbank accession number AY217766 [15]

${ }^{\mathrm{a}}$ bmr12-34 and bmr12-820 contain two mutations in Bmr12, which are identical

with the mode of action of the mutagen EMS (Table 1). Interestingly, the same two missense mutations within the Bmrl2 coding region were identified in bmr12-34 and bmr12-820, which most likely resulted from the same mutation events and shared a pollen parent. These four base pair transitions caused missense mutations resulting in changes in conserved amino acids throughout the protein (Table 1 and Fig. 1). In all four cases, the amino acid residue was nearly invariant between similar $O$-methyltransferase proteins across vascular plant including monocots, dicots, gymnosperms, and the primitive vascular plant Selaginella moellendorffii (Fig. 1). The one exception is Ala71, which is a Ser in Selaginella. Based on previously published crystal structures of COMT proteins from other plants, these mutations did not affect amino acids involved in substrate binding, SAM binding, catalysis, or that are present in the active site. However, Gly225Asp was proximal to Asp229 and Leu230, which were shown to be involved in SAM binding (Fig. 1) [29, 30]. Gly325Ser was proximal to Asn323 and Glu328, which were shown to be involved in binding and positioning of the phenolic substrate; Asn323 has been shown to $\mathrm{H}$ bond with the 4-hydroxyl group (Fig. 1) [29, 30]. Although Ala71 and Pro150 are not directly involved in dimerization, Ala71Val and Pro150Leu occurred within the dimerization domain of protein [29], which might be relevant to their effect on enzymatic activity.

\section{Bmr12 Gene Expression}

To examine the effect these mutations have on Bmr12 gene expression, total RNA was extracted from 5-week-old sorghum stalks, and the gene expression of Bmrl2 was determined using RT-qPCR. The mutants examined did not have a significant impact on Bmr 12 gene expression compared to WT with the exception of bmr12-ref (Fig. 2). In bmr12-ref stalks, Bmr 12 expression was reduced approximately 77 - 
Fig. 1 Amino acid sequence alignment of caffeic $O$-methyltransferase genes. Predicted amino acid sequences for caffeic $O$-methyltransferase genes from a range of plant species (Genbank accession no. or alternative gene identifier): Picea abies PaOMT (CAI30878), Pinus taeda PtOMT (TC98491; DFCI Gene Indices), Selaginella moellendorffii SmCOMT (438615; Phytozome), Arabidopsis thaliana AtCOMT (At5g54160), Medicago sativa MsCOMT (AAB46623), Clarkia breweri CbCOMT (O23760), Eucalyptus gunnii EgCOMT (CAA52814), Triticum aestivum TaCOMT (AAP23942), Lolium perenne LpOMT1 (AAD10253), Z. mays Bm3 (AAQ24340.1), Saccharum officinarum SoCOMT (O82054), and Sorghum bicolor Bmr12 (Sb07g003860.1; AAO43609) were aligned using ClustalW (see the "Materials and Methods" section). The aligned amino acid sequences include the 20 amino acids surrounding the sorghum bmr12 missense mutations described in this article, which are denoted by an asterisk. Dark gray shading denotes conserved amino acids and light gray shading denotes similar amino acids. Underlined segments denote conserved amino acid residues involved in substrate binding or catalysis

fold relative WT, which is consistent with the previously published Northern blot results [15]. Nonsense mediated decay likely explained the major reduction of these transcripts in bmr12-ref, which encodes a nonsense mutation within the coding region [15]. Overall, absence of effects on Bmrl2 gene expression is consistent with missense mutants, which rarely alter gene expression of their own gene.

\section{Bmr12 Protein and Enzymatic Activity}

To examine the effect these mutations have on the Bmr12 protein, total proteins were extracted from 6-week-old sorghum stalks, separated by SDS-PAGE, and Bmr12 was detected on an immunoblot using a polyclonal antibody against Bmr12. Bmr12 protein was not detected in bmr12ref protein extracts as previously shown using this antibody [16] (Fig. 3). The Bmr12 protein was nearly undetectable in bmr12-30 extracts (Fig. 3), which suggests the Gly225Asp change caused the protein to be misfolded and proteolyzed. This conclusion is consistent with the Bmrl2 gene expression in bmr12-30, which was comparable to WT (Fig. 2). The Bmr12 protein was also reduced in bmr12-820 extracts (Fig. 3). Bmr12 was detected at levels comparable to WT in bmr12-34 and bmr12-35 based on detection of the loading control with a polyclonal antibody against ascorbate peroxidase, which recognizes both cytosolic and plastidic protein isoforms (Fig. 3).

To determine how these mutations affect enzymatic activity, the WT Bmr12 protein and the mutated forms of Bmr12 corresponding to the four missense mutations were expressed in E. coli and purified, because previously sorghum extracts were shown to be incompatible to the COMT enzyme assay [24]. Even when an excess of purified recombinant Bmr12 protein was added to sorghum extracts, the assay failed to detect enzyme activity [24]. However, in switchgrass crude extracts, COMT enzyme activity was
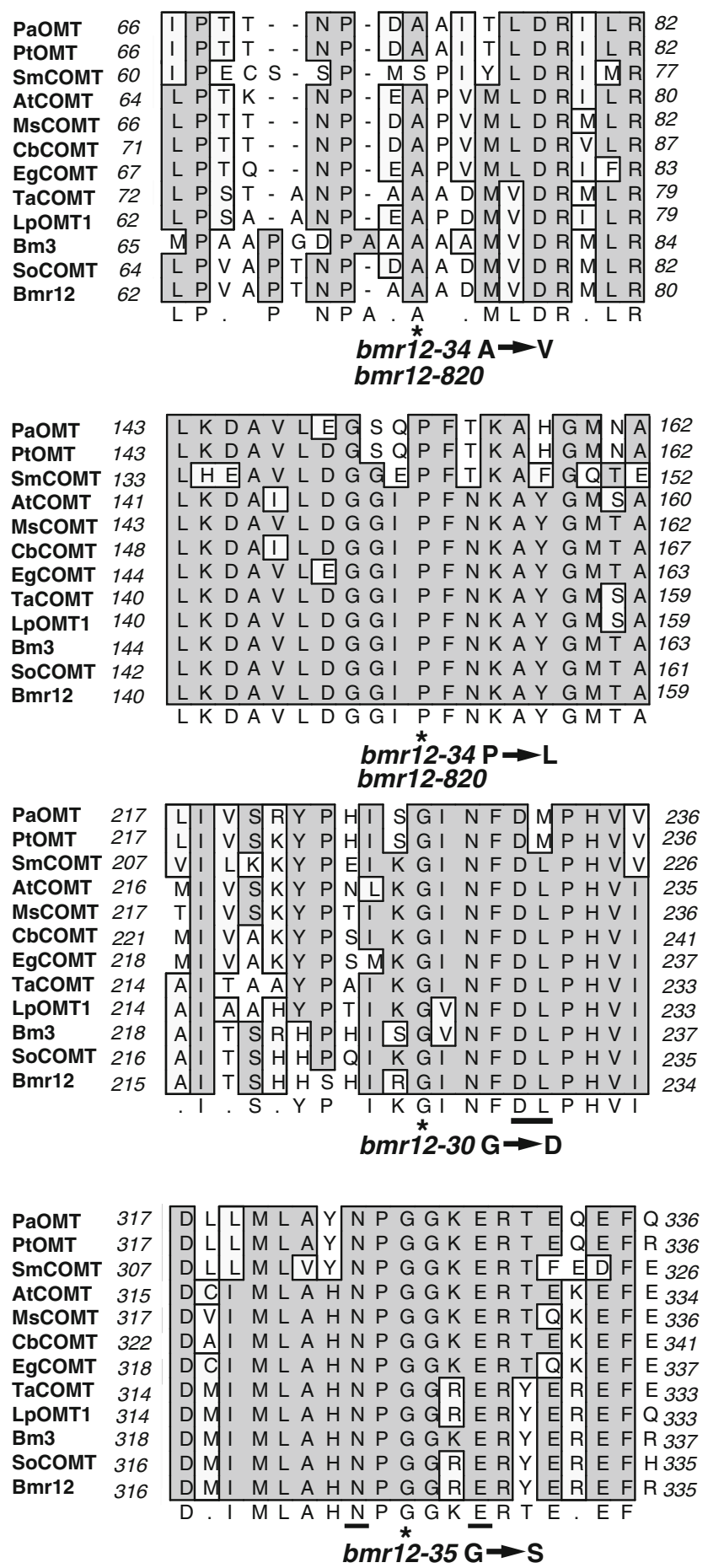

fully detectable [24]. As such, we chose to perform the assay using E. coli-expressed proteins. All the mutated forms of the protein were expressed and purified except for Gly225Asp (bmr12-30), which resulted in a truncated protein, which was insoluble (Supplementary Fig. 1). This result suggests that Gly225Asp (bmr12-30) caused the protein to be misfolded and cleaved, which is consistent with the immunoblot results (Fig. 3). Enzymatic activity was quantified using a previously 


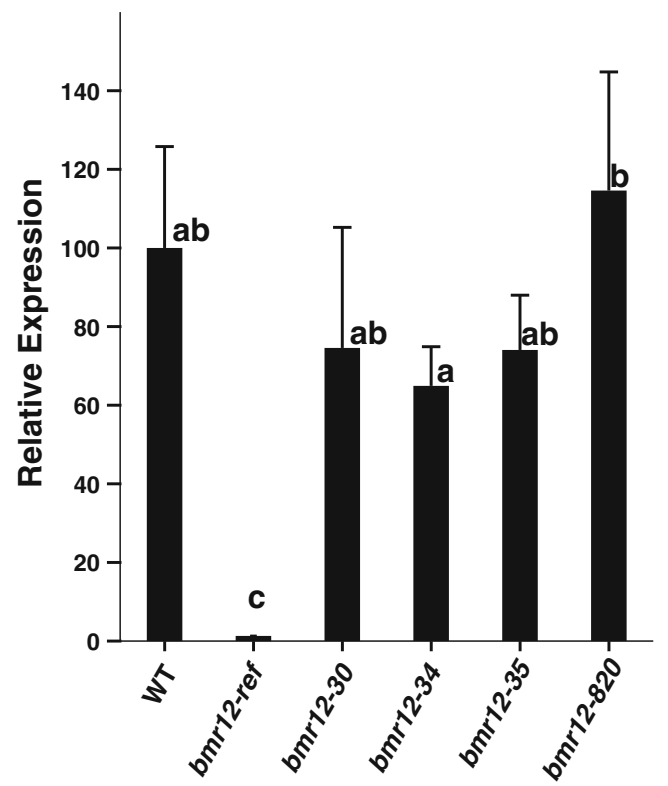

Fig. 2 Relative RNA expression of Bmr12 in 5-week-old sorghum stalks. Total RNA was extracted from wild-type (WT) and bmr12 stalks. RT-qPCR was used to quantify RNA expression of Bmr12 and relative expression was determined using $\Delta \Delta C_{\mathrm{t}}$ method (see the "Materials and Methods" section for further details). Bmr12 gene expression was expressed relative to WT levels. Means with differing letters differ at $P=0.05$ using an $F$-protected LSD $(n=3)$

described continuous assay [24]. Enzymatic activity was reduced slightly to $82 \%$ of WT activity for the Ala71Val (first mutation in bmr12-34/820, Fig. 4). Pro150Leu (second mutation in bmr12-34/820) and Gly325Ser (bmr12-35) severely affected enzyme activity relative to the WT activity (Fig. 4). Gly325Ser (bmr12-35) recombinant protein had approximately $1.2 \%$ of WT activity. Pro150Leu recombinant protein had 800-fold less activity than WT, and combining Ala71Val and Pro150Leu together, which occurred together in bmr12-34 and bmr12-820, further reduced enzymatic activity to approximately 4,000-fold less than WT activity (Fig. 4). Overall, the missense mutants significantly impaired assayed enzymatic activity, with the exception of Ala71Val (first mutation in bmr12-34/820).

\section{Lignin Content and Enzymatic Saccharification}

To determine the effect these mutations had on lignin content, Klason lignin content in lignocellulosic biomass from field-grown plants was measured (Table 2). All the bmr12 mutants examined had statistically significantly reduced Klason lignin content in their biomass relative to WT BTx623. The greatest reduction in lignin content relative to WT $(-21.5 \%)$ was observed in bmr12-820 biomass. The lignin content in bmr12-30 and -34 biomass was intermediate; Klason lignin was reduced by 13.2 and $9.0 \%$, respectively. The biomass from bmr12-35 had the smallest reduction in lignin content relative to WT $(-7.5 \%)$ for this allelic series. Although bmr12-820 and bmr12-34 contain the same two mutations within the Bmr12 gene, their lignin contents were significantly different, which suggests that a mutation at another locus in either bmr12-34 or bmr12-820 has influenced lignin content. The observed reduction in Klason lignin content in these $b m r 12$ mutants is consistent with the previously described effects of bmr 12 on cell wall lignification.

To assess the effect these mutants had on lignin subunit composition, washed cell wall material from mature stalks was analyzed by thioacidolysis. Thioacidolysis cleaves $\beta-O-4$ bonds within the lignin polymer. The resulting monomer constituents were derivatized for analysis by GC-MS. Relative to WT stalk tissue, monomer levels and monomer composition were altered in all of the bmr12 alleles (Fig. 5a). The content of $\mathrm{S}$ subunits was severely reduced in all $b m r 12$ mutants; the lowest level was observed in bmr12-ref, followed by bmr12-30, bmr12-820, and bmr12-34. The bmr12-35 mutant retained a modest level of S subunits, roughly half the level observed in WT tissue. The content of G subunits was also reduced in bmr 12 alleles relative to WT, albeit modestly. These changes in subunit composition translated into considerably reduced $\mathrm{S} / \mathrm{G}$ ratios in the $b m r 12$ mutants. The smallest ratio was observed in bmr12-ref (0.0304); bmr12-820

\section{a}

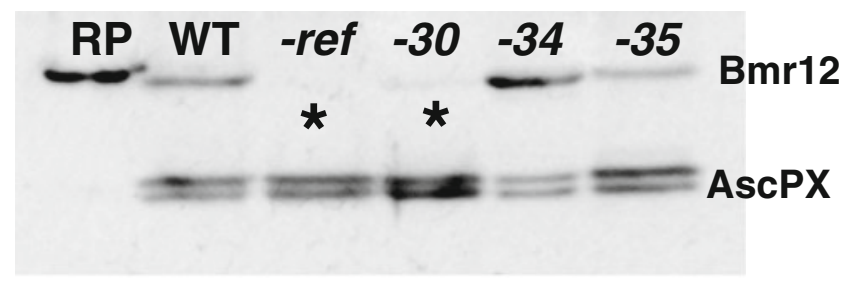

b

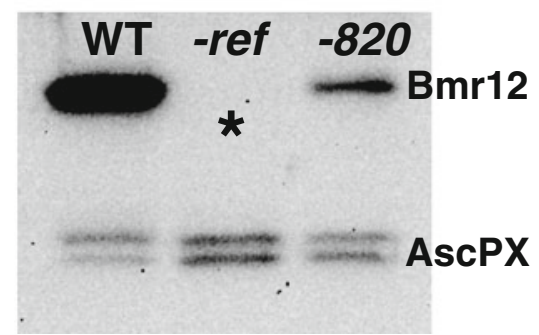

Fig. 3 Immunoblot detection of Bmr12 from 6-week-old sorghum stalks. Protein extracts from wild-type $(W T)$ and $b m r 12$ stalks were separated by SDS-PAGE, transferred to membrane, and probed with polyclonal antibodies raised against the $\mathrm{N}$-terminus of recombinant Bmr12 protein in rabbits [16]. AscPx antibody was raised against purified soybean root nodule ascorbate peroxidase in rabbits. This antibody was used as a loading and transfer control. a Recombinant Bmr12 (RP), WT extracts (WT), bmr12-ref (-ref), bmr12-30 extracts $(-30)$, bmr12-34 extracts (-34), and bmr12-35 extracts (-35). b WT extracts (WT), bmr12-ref (-ref), bmr12-820 extracts (-820). Asterisks denote the absence of the Bmr12 protein in bmr12-ref and bmr12-30 extracts. See the "Materials and Methods" section for further details 


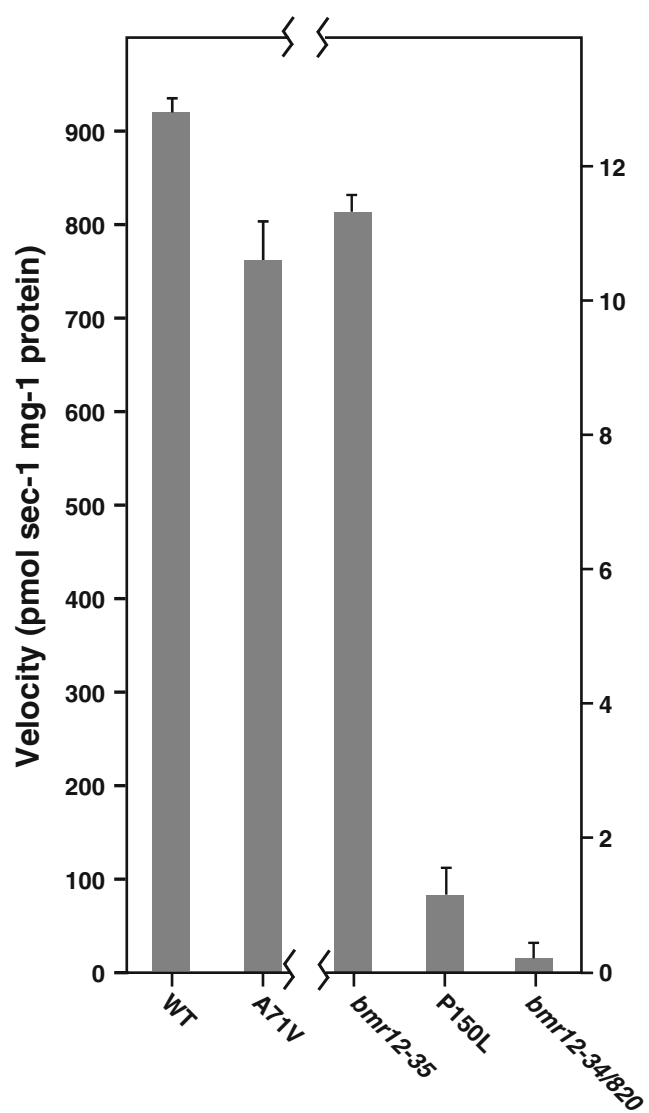

Fig. 4 Enzyme activity of Bmr12 and mutated versions of protein. COMT enzymatic activity from recombinant proteins was determined using a continuous fluorescent assay previously developed and described [24]. 3,4-Dihydroxy-5-methoxybenzaldehyde at $40 \mu \mathrm{M}$ was used as the substrate. The enzyme velocity was normalized to the amount of protein. The scale on the left corresponds to the first two columns and the scale on the right corresponds to the last three columns. The recombinant protein containing both Ala71 Val and Pro150Leu amino acid changes corresponds to bmr12-34/820. The recombinant protein containing Gly325Ser corresponds to bmr12-35. Error bars denote SE $(n=4)$. See the "Materials and Methods" section for further details

(0.0750), bmr12-30 (0.0752), and bmr12-34 (0.0806) were intermediate; and bmr12-35 (0.424) had the highest ratio among the mutants, closest to WT $(0.625$, Fig. 5a). The content of $\mathrm{H}$ subunits was also modestly reduced relative to WT in all of the bmr 12 mutants examined (Fig. 5b). The lignin polymers of the bmr 12 alleles contained elevated 5-hydroxy guaiacyl lignin levels relative to WT, because the COMT substrate 5-hydroxyconiferylalcohol was incorporated in the lignin polymer. The highest levels were observed in bmr12-ref and $b m r 12-34$, and intermediate levels were observed in bmr12-820, bmr12-30, and bmr12-35 (Fig. 5b). 5-Hydroxy guaiacyl residues were detected in WT tissue, but at levels that were over fourfold lower relative to the intermediate levels in bmr12-30 and bmr12-35, and over eightfold lower compared to the high levels observed in bmr12-ref, bmr12-35, and bmr12-820. Overall, these data indicated that the bmrl2 missense alleles altered lignin composition in a manner consistent with reduced enzymatic activity.

To assess the potential these alleles have to improve cellulosic conversion, $300 \mathrm{mg}$ of ground lignocellulosic material from mature stalk tissue was washed and enzymatically saccharified using cellulases at a loading of $60 \mathrm{FPU} / \mathrm{g}$. The yield of glucose released was measured after 4, 20, and $96 \mathrm{~h}$ of saccharification (Table 2). All the bmrl2 alleles examined had statistically greater glucose release than WT at 20 and $96 \mathrm{~h}$, except for bmr12-35. The highest release of glucose was observed from bmr12-820 tissue followed by bmr12-34, bmr12-30, bmr12-ref, and WT at 20 and $96 \mathrm{~h}$. The improved glucose yields were maintained after pretreatment in dilute sulfuric acid (Table 2). Based on these assays, all bmr12 alleles except bmr12-35 appear to improve cellulosic conversion rates.

\section{Discussion}

We have identified and characterized four novel missense mutations in Bmr12, the sorghum COMT gene. These mutations resulted in changes to amino acid residues that are nearly invariant across vascular plants. The previously characterized bmr12 mutants: bmr12-ref, bmr12-18, bmr12-25, and $b m r 12-26$ all contain premature stop codons [13, 15, 19], and are likely null alleles encoding nonfunctional forms of the enzyme. These newly discovered alleles represent the first allelic series of bmr 12 mutants derived from the same varietal background to investigate the impact of these mutants on Bmr12 gene expression, enzymatic activity, lignin content, and composition and biomass conversion. These missense mutations in Bmr12 (Ala71Val, Pro150Leu, and Gly325Ser) were also identified in recent studies [22].

The effects of these missense mutations were examined in the context of protein function. Changing an evolutionarily conserved amino acid residue to a dissimilar amino acid (an Asp replaced Gly225) substantially decreased the steady-state level of the Bmr12 protein in bmr12-30 (Fig. 3). The premature stop codon in the bmr12-ref allele resulted in undetectable levels of the Bmr12 protein in plant extracts (Fig. 3) [16], and therefore, this allele likely represents a null allele of Bmr12. The gene expression results (Fig. 2) indicated that neither a transcriptional nor a posttranscriptional reduction of Bmr 12 transcripts was responsible for the near absence of the protein in bmr12-30 (Fig. 3). Hence, the Gly225Asp change in bmr12-30 likely destabilized the protein causing misfolding and subsequent protein degradation. Interestingly, we were unable to express Gly225Asp altered COMT protein in E. coli cells; this amino acid change resulted in a truncated protein product (Supplementary Figure 1). This result suggested that the mutated form of the protein was also misfolded in E. coli, and an endogenous 
Table 2 Variation in Klason lignin content and glucose yields obtained after enzymatic saccharification at $50{ }^{\circ} \mathrm{C}$ at $60 \mathrm{FPU} / \mathrm{g}$ cellulase of native (unpretreated) stover after 4, 20 , and $96 \mathrm{~h}$, and of pretreated stover after $24 \mathrm{~h}$

${ }^{\mathrm{a}}$ Means in rows with different letters are statistically significant based on Tukey's HSD with an experiment-wise error rate of $0.05(n=9)$

\begin{tabular}{|c|c|c|c|c|c|}
\hline & \multirow{3}{*}{$\begin{array}{l}\text { Klason lignin (mg/g) } \\
\text { Mean (SD) }\end{array}$} & \multicolumn{4}{|c|}{ Glucose yield (mg/g stover) } \\
\hline & & \multicolumn{2}{|l|}{ Unpretreated } & \multicolumn{2}{|l|}{ Pretreated } \\
\hline & & $\begin{array}{l}4 \mathrm{~h} \\
\text { Mean }(\mathrm{SD})^{\mathrm{a}}\end{array}$ & $\begin{array}{l}20 \mathrm{~h} \\
\text { Mean (SD) }\end{array}$ & $\begin{array}{l}96 \mathrm{~h} \\
\text { Mean (SD) }\end{array}$ & $\begin{array}{l}24 \mathrm{~h} \\
\text { Mean (SD) }\end{array}$ \\
\hline WT BTx623 & $21.2(1.9) \mathrm{a}$ & $38(6) b c$ & $54(5) \mathrm{d}$ & $55(4) d$ & $174(25) \mathrm{c}$ \\
\hline bmr12-ref & $17.1(0.8) \mathrm{cd}$ & $42(6) \mathrm{abc}$ & $62(5) \mathrm{cd}$ & 64 (8)bcd & $212(19) \mathrm{b}$ \\
\hline bmr12-30 & $18.4(0.9) \mathrm{bc}$ & $43(13) a b c$ & $64(7) b c$ & $70(8) \mathrm{abc}$ & $230(27) a b$ \\
\hline bmr12-34 & $19.3(1.5) \mathrm{b}$ & $51(10) \mathrm{ab}$ & $74(9) \mathrm{ab}$ & $74(9) \mathrm{ab}$ & $213(22) b$ \\
\hline bmr12-820 & $16.7(1.7) \mathrm{d}$ & $54(14) \mathrm{a}$ & $79(12) \mathrm{a}$ & $82(13) a$ & $238(35) \mathrm{a}$ \\
\hline bmr12-35 & $19.6(0.5) \mathrm{ab}$ & $32(7) \mathrm{c}$ & $54(6) \mathrm{d}$ & $59(12) \mathrm{cd}$ & $178(12) \mathrm{c}$ \\
\hline HSD $(0.05)$ & 2.2 & 10 & 8.3 & 9.9 & 22 \\
\hline
\end{tabular}
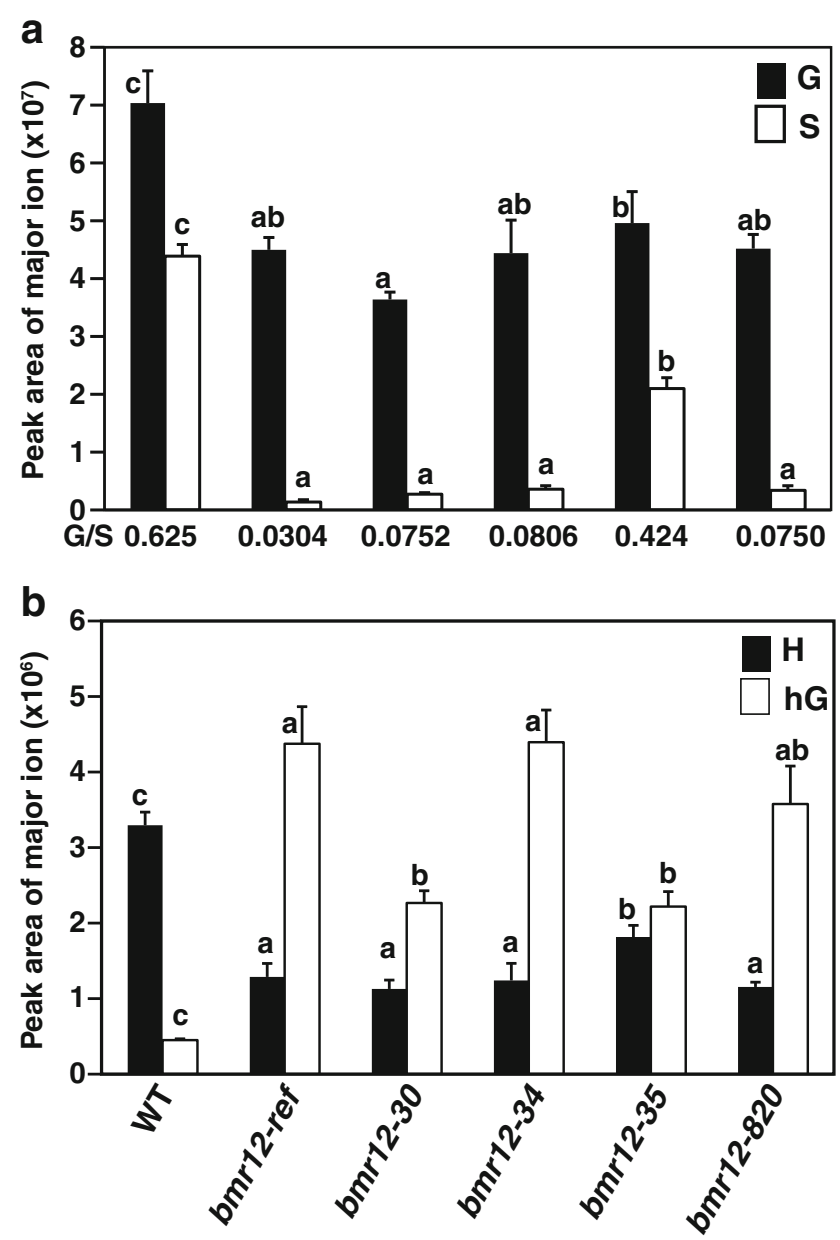

Fig. 5 Lignin composition in wild-type (WT) and the bmr12 mutants. a Distribution of major lignin subunits $\mathrm{G}$ lignin $(G$; black bars) and $\mathrm{S}$ lignin $(S$; white bars) in stalks from WT and bmr12 alleles were quantified by GC-MS following thioacidolysis. b Minor lignin subunits were determined by abundance of ions diagnostic of $\mathrm{H}$ lignin ( $H$; black bars) and 5-hydroxy $\mathrm{G}$ lignin $(h G$; white bars) in stalks. Error bars denote SE $(n=4)$. Means with differing letters differ at $P=0.05$ using an $F$-protected LSD. See the "Materials and Methods" section for further details protease subsequently cleaved this protein. The size of the protein fragment observed on SDS-PAGE differed from the expected peptide fragments if the cleavage occurred at Gly225Asp, which suggested the cleavage occurred at another site. Based on protein accumulation, bmr12-30 is likely another strong mutant allele similar to bmr12-ref as opposed to bmr12-34 and bmr12-35, which did not affect steady-state Bmr12 level. Examining COMT activity of the recombinant proteins containing the amino acid changes identified in bmr12-34/820 and bmr12-35 showed that these three mutations (Ala71Val, Pro150Leu, Gly325Ser) clearly reduced enzyme activity compared to WT. Ala71Val reduced COMT activity by $18 \%$, but in bmr12-34/820, the protein contained both Ala71Val and Pro150Leu changes. Combined together Ala71Val with Pro150Leu reduced enzyme activity to approximately 4,000-fold less than WT activity, but the residual activity of this recombinant protein was still detectable relative to the negative control. In contrast, Gly325Ser (bmr12-35) retained approximately $1.2 \%$ of WT activity, 48-fold more activity than Ala71 Val/Pro150Leu protein (bmr12-34/820). Based on protein and enzyme analysis, bmr12-35 should retain significantly more enzyme activity than bmr12-30, bmr12-34, and bmr12-820.

The impact these missense mutations had on lignin content and composition is consistent with either absence of Bmr12 protein or reduction of enzymatic activity. All the mutants examined significantly reduced Klason lignin content relative to $\mathrm{WT}$. All their $\mathrm{S} / \mathrm{G}$ ratios are drastically decreased compared to WT due to the reduced synthesis of sinapyl alcohol. The bmr12-30, bmr12-34, and bmr12-820 mutants had $\mathrm{S} / \mathrm{G}$ ratios that were very small, but still more than twofold higher than bmr12-ref. bmr12-30 and bmr1234 biomass also had significantly higher Klason lignin relative to bmr12-ref. Together, these results suggest that bmr12-30, bmr12-34, and bmr12-820 may retain very minute amounts of enzyme activity, which is completely absent from bmr12-ref. The enzyme assays also support this 
hypothesis for bmr12-34/bmr12-820. The one clear discrepancy is the lignin content of $b m r 12-820$, which was slightly lower than bmr12-ref but significantly lower than bmr12-34, even though both bmr12-34 and bmr12-820 contained the same two bmr 12 mutations. A plausible explanation is that bmr12-34 and bmr12-820 differ at another locus, resulting in even lower lignin content in bmr12-820. Clearly, bmr1235 is a hypomorphic (weak) allele, because it has an intermediate lignin content relative to WT and bmr12-ref, an intermediate $\mathrm{S} / \mathrm{G}$ ratio compared to other bmr12 mutants and WT and retained some enzyme activity. The 83-fold reduction in enzyme activity of the Gly325Ser recombinant protein translated into a modest reduction in Klason lignin and intermediate $\mathrm{S} / \mathrm{G}$ in bmr12-35, which suggests this enzyme assay may magnify the effects of the missense amino acid change on enzyme activity. Alternatively, the Bmr12 (COMT) capacity of the plant could greatly exceed its requirement for sinapyl alcohol synthesis. Even in the putative null allele bmr12-ref, which lacks any detectable Bmr12 protein, S lignin subunits were still detectable [16]. These results indicate that other $O$-methyltransferases within sorghum are capable of catalyzing this reaction in the absence of Bmr12, and one potential candidate is the enzyme caffeoylCoA $O$-methyltransferase, which has been shown to perform a similar role in Arabidopsis COMT-deficient plants [31].

Except for bmr12-35, all bmr12 mutants examined significantly increased glucose yield from biomass following enzymatic saccharification relative to WT, even after dilute sulfuric acid pretreatment. Even though the lignin content and $\mathrm{S} / \mathrm{G}$ ratio are significantly reduced in $b m r 12-35$, its glucose yield was not significantly different from WT. Although the bmr12-34 mutant has a similar reduction in Klason lignin content compared to bmr12-35, it has a significantly lower $\mathrm{S} / \mathrm{G}$ ratio as well as lower enzyme activity. These observations suggest that in order to achieve higher saccharification yields, lignin content and/or S/G ratio must be reduced below certain thresholds. The increased glucose yield appears to primarily result from the greater reduction of $\mathrm{S} / \mathrm{G}$ ratio due to reduced sinapyl alcohol content. This observation is consistent with other bmr 12 mutants with low $\mathrm{S} / \mathrm{G}$ ratios. Based on these data, the $\mathrm{S} / \mathrm{G}$ ratio necessary to improve glucose yields is between 0.081 and 0.423 , and additional research is needed to narrow the range down further. The reductions in Klason lignin content observed were much smaller compared to changes in lignin composition, so $S / G$ ratio is a likely more sensitive metric for evaluating these mutants. In $b m r 12$, the reduced $\mathrm{S} / \mathrm{G}$ and reduced lignin content are linked, because bmrl2 mutants are primarily reduced in lignin content through the reduction of S lignin. More importantly, these results suggest that improvement of conversion of grass cell walls may require a fundamentally different approach than in angiosperm dicots, where reduced lignin content
[5] or a high $\mathrm{S} / \mathrm{G}$ ratio, the opposite of bmr12 mutants, was shown to be favorable [32].

In summary, these missense alleles of bmr 12 represent new tools to modify lignin content and composition to increase biomass conversion efficiency. Multiple rounds of backcrossing will be required to remove other mutations generated by the mutagen and understand the impact that these bmr 12 missense mutations have agronomic traits such as yield. Going beyond this study, these alleles could be combined with each other or with the previously characterized $b m r 12$ alleles to form interallelic hybrids in the same or in a hybrid background. This approach has the potential to modulate both lignin content and composition ( $\mathrm{S} / \mathrm{G}$ ratio), similar to transgenic approaches to downregulate COMT in plant species $[9,33,34]$, but with relatively greater stability. The thresholds for altering lignin composition and content to increase bioenergy conversion for sorghum remain to be determined.

Acknowledgments We thank Tammy Gries, Nathan Peroutka-Bigus and John Toy for their technical assistance with experimental data presented in this manuscript, Dr. Lisa Durso for the use of her realtime PCR instrument, and Dr. Heather Van Buskirk for critically reviewing the manuscript. This research was supported by National Institute of Food \& Agriculture, Grant 2011-67009-30026 (S.E.S, J.F.P), the Office of Science (BER), U.S. Department of Energy, grant DEFG02-07ER64458 (W.V., S.E.S, J.F.P), and additional funding from USDA-ARS, CRIS project 5440-21220-024-00D (S.E.S, J.F.P).

\section{References}

1. Sarath G, Mitchell RB, Sattler SE, Funnell D, Pedersen JF, Graybosch RA, Vogel KP (2008) Opportunities and roadblocks in utilizing forages and small grains for liquid fuels. $\mathrm{J}$ Ind Microbiol Biotechnol 35(5):343-354

2. Schmer MR, Vogel KP, Mitchell RB, Perrin RK (2008) Net energy of cellulosic ethanol from switchgrass. Proc Natl Acad Sci U S A 105(2):464-469

3. Jung HJG, Ni W (1998) Lignification of plant cell walls: impact of genetic manipulation. Proc Natl Acad Sci U S A 95(22):1274212743

4. Boerjan W, Ralph J, Baucher M (2003) Lignin biosynthesis. Annu Rev Plant Biol 54:519-546

5. Chen F, Dixon RA (2007) Lignin modification improves fermentable sugar yields for biofuel production. Nat Biotechnol 25 (7):759-761. doi: $10.1038 /$ nbt1316

6. Dien BS, Sarath G, Pedersen JF, Sattler SE, Chen H, FunnellHarris DL, Nichols NN, Cotta MA (2009) Improved sugar conversion and ethanol yield for forage sorghum (Sorghum bicolor L. Moench) lines with reduced lignin contents. BioEnergy Research 2:153-164. doi:10.1007/s12155-009-9041-2

7. Vermerris W, Saballos A, Ejeta G, Mosier NS, Ladisch MR, Carpita NC (2007) Molecular breeding to enhance ethanol production from corn and sorghum stover. Crop Sci 47(suppl DEC): S147-S153

8. Ruel K, Berrio-Sierra J, Derikvand MM, Pollet B, Thévenin J, Lapierre C, Jouanin L, Joseleau JP (2009) Impact of CCR1 silencing on the assembly of lignified secondary walls in Arabidopsis thaliana. New Phytol 184(1):99-113 
9. Piquemal J, Lapierre C, Myton K, O'Connell A, Schuch W, GrimaPettenati J, Boudet AM (1998) Down-regulation of cinnamoyl$\mathrm{CoA}$ reductase induces significant changes of lignin profiles in transgenic tobacco plants. Plant J 13(1):71-83

10. Jones L, Ennos AR, Turner SR (2001) Cloning and characterization of irregular xylem4 (irx4): a severely lignin-deficient mutant of Arabidopsis. Plant J 26(2):205-216

11. Sattler SE, Funnell-Harris DL, Pedersen JF (2010) Brown midrib mutations and their importance to the utilization of maize, sorghum, and pearl millet lignocellulosic tissues. Plant Sci 178 (3):229-238

12. Ali F, Scott P, Bakht J, Chen Y, Lübberstedt T (2010) Identification of novel brown midrib genes in maize by tests of allelism. Plant Breed 129(6):724-726

13. Saballos A, Vermerris W, Rivera L, Ejeta G (2008) Allelic association, chemical characterization and saccharification properties of brown midrib mutants of sorghum (Sorghum bicolor (L.) Moench). BioEnergy Research 1(3):193-204

14. Vignols F, Rigau J, Torres MA, Capellades M, Puigdomenech P (1995) The brown midrib3 (Bm3) mutation in maize occurs in the gene encoding caffeic acid $O$-methyltransferase. Plant Cell 7 (4):407-416

15. Bout S, Vermerris W (2003) A candidate-gene approach to clone the sorghum Brown midrib gene encoding caffeic acid $O$-methyltransferase. Mol Genet Genomics 269(2):205-214

16. Palmer NA, Sattler SE, Saathoff AJ, Funnell D, Pedersen JF, Sarath G (2008) Genetic background impacts soluble and cell wall-bound aromatics in brown midrib mutants of sorghum. Planta 229(1):115-127

17. Oliver AL, Pedersen JF, Grant RJ, Klopfenstein TJ (2005) Comparative effects of the sorghum bmr- 6 and bmr- 12 genes: I. Forage sorghum yield and quality. Crop Sci 45(6):2234-2239

18. Oliver AL, Pedersen JF, Grant RJ, Klopfenstein TJ, Jose HD (2005) Comparative effects of the sorghum bmr-6 and bmr-12 genes: II. Grain yield, stover yield, and stover quality in grain sorghum. Crop Sci 45(6):2240-2245

19. Porter KS, Axtell JD, Lechtenberg VL, Colenbrander VF (1978) Phenotype, fiber composition, and in vitro dry matter disappearance of chemically induced brown midrib (bmr) mutants of sorghum. Crop Sci 18:205-208

20. Pedersen JF, Funnell DL, Toy JJ, Oliver AL, Grant RJ (2006) Registration of twelve grain sorghum genetic stocks nearisogenic for the brown midrib genes bmr-6 and bmr-12. Crop Sci 46(1):491-492

21. Xin Z, Wang M, Burow G, Burke J (2009) An induced sorghum mutant population suitable for bioenergy research. BioEnergy Research 2(1):10-16

22. Xin Z, Wang ML, Barkley NA, Burow G, Franks C, Pederson G, Burke J (2008) Applying genotyping (TILLING) and phenotyping analyses to elucidate gene function in a chemically induced sorghum mutant population. BMC Plant Biol 8:103. doi:10.1186/ 1471-2229-8-103

23. Sattler SE, Saathoff AJ, Haas EJ, Palmer NA, Funnell-Harris DL, Sarath G, Pedersen JF (2009) A Nonsense mutation in a cinnamyl alcohol dehydrogenase gene is responsible for the Sorghum brown midrib6 phenotype. Plant Physiol 150(2):584-595. doi:10.1104/ pp. 109.136408

24. Palmer NA, Sattler SE, Saathoff AJ, Sarath G (2010) A continuous, quantitative fluorescent assay for plant caffeic acid $O$-methyltransferases. J Agric Food Chem 58(9):5220-5226

25. Theander O, Westerlund EA (1986) Studies on dietary fiber. 3. Improved procedures for analysis of dietary fiber. J Agric Food Chem 34(2):330-336

26. Hatfield RD, Jung HJG, Ralph J, Buxton DR, Weimer PJ (1994) A comparison of the insoluble residues produced by the Klason lignin and acid detergent lignin procedures. J Sci Food Agric 65 (1):51-58. doi:10.1002/jsfa.2740650109

27. Adney B, Baker J (1996) Measurement of cellulase activities. LAP-006 NREL Analytical Procedure

28. Paterson AH, Bowers JE, Bruggmann R, Dubchak I, Grimwood J, Gundlach H, Haberer G, Hellsten U, Mitros T, Poliakov A, Schmutz J, Spannagl M, Tang HB, Wang XY, Wicker T, Bharti AK, Chapman J, Feltus FA, Gowik U, Grigoriev IV, Lyons E, Maher CA, Martis M, Narechania A, Otillar RP, Penning BW, Salamov AA, Wang Y, Zhang LF, Carpita NC, Freeling M, Gingle AR, Hash CT, Keller B, Klein P, Kresovich S, McCann MC, Ming R, Peterson DG, Mehboob-ur-Rahman WD, Westhoff P, Mayer KFX, Messing J, Rokhsar DS (2009) The Sorghum bicolor genome and the diversification of grasses. Nature 457(7229):551556. doi:10.1038/Nature 07723

29. Louie GV, Bowman ME, Tu Y, Mouradov A, Spangenberg G, Noel JP (2010) Structure-function analyses of a caffeic acid $O$-methyltransferase from perennial ryegrass reveal the molecular basis for substrate preference. Plant Cell 22(12):4114-4127

30. Zubieta C, Kota P, Ferrer JL, Dixon RA, Noel JP (2002) Structural basis for the modulation of lignin monomer methylation by caffeic acid/5-hydroxyferulic acid 3/5-O-methyltransferase. Plant Cell 14 (6): 1265-1277

31. Do CT, Pollet B, Thevenin J, Sibout R, Denoue D, Barriere Y, Lapierre C, Jouanin L (2007) Both caffeoyl Coenzyme A 3-Omethyltransferase 1 and caffeic acid O-methyltransferase 1 are involved in redundant functions for lignin, flavonoids and sinapoyl malate biosynthesis in Arabidopsis. Planta 226(5):11171129

32. Studer MH, DeMartini JD, Davis MF, Sykes RW, Davison B, Keller M, Tuskan GA, Wyman CE (2011) Lignin content in natural Populus variants affects sugar release. Proc Natl Acad Sci U S A 108(15):6300-6305

33. Lapierre C, Pollet B, Petit-Conil M, Toval G, Romero J, Pilate G, Leplé JC, Boerjan W, Ferret V, De Nadai V, Jouanin L (1999) Structural alterations of lignins in transgenic poplars with depressed cinnamyl alcohol dehydrogenase or caffeic acid $O$-methyltransferase activity have an opposite impact on the efficiency of industrial kraft pulping. Plant Physiol 119(1):153-163

34. Parvathi K, Chen F, Guo D, Blount JW, Dixon RA (2001) Substrate preferences of $O$-methyltransferases in alfalfa suggest new pathways for 3-O-methylation of monolignols. Plant J 25(2):193-202 
Supplementary Fig. 1:

Expression of recombinant Bmr12 proteins in E. coli. The recombinant proteins were expressed E. coli cells and purified using an $\mathrm{N}$-terminal $6 \mathrm{His}$ tag. See "Materials and Methods" section for further details. a SDS-PAGE analysis of the proteins prior to purification from the induced E. coli cells Lane 1 molecular weight marker, lane 2 WT Bmr12, lane 3 Ala225Asp. Arrows denote the $B m r 12$ protein and a truncated form occurring in the recombinant protein Ala225Asp, which corresponds to bmr12-30. b SDS-PAGE analysis of the purified proteins from the induced $\mathrm{E}$. coli cells. Lane 1 molecular weight marker, lane 2 WT Bmr12, lane 3 Gly325Ser, lane 4 Pro150Leu, lane 5 Ala71Val, lane 6 Ala71Val Pro150Leu. The recombinant protein containing Gly325Ser corresponds to bmr12-35. The recombinant protein containing both Ala71Val and Pro150Leu amino acid changes corresponds to bmr12-34/820. The molecular weights of the markers are as follows: $200,116.25,97.4,66.2$ $45.0,31.0$, and $21.5 \mathrm{kDa}$ (JPEG $24 \mathrm{~kb}$ )

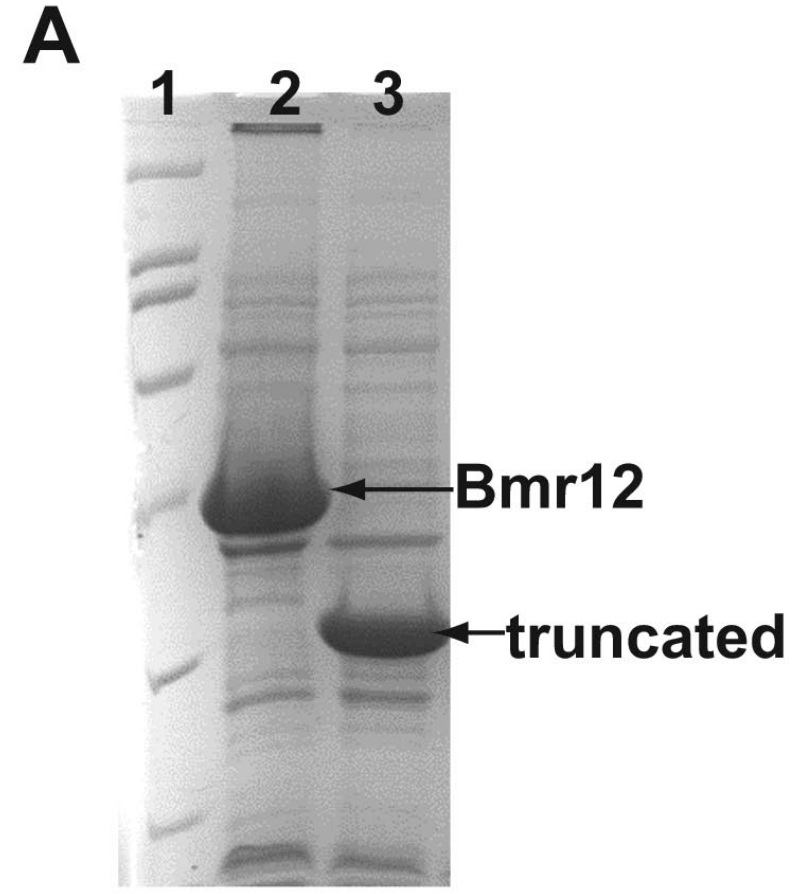

B

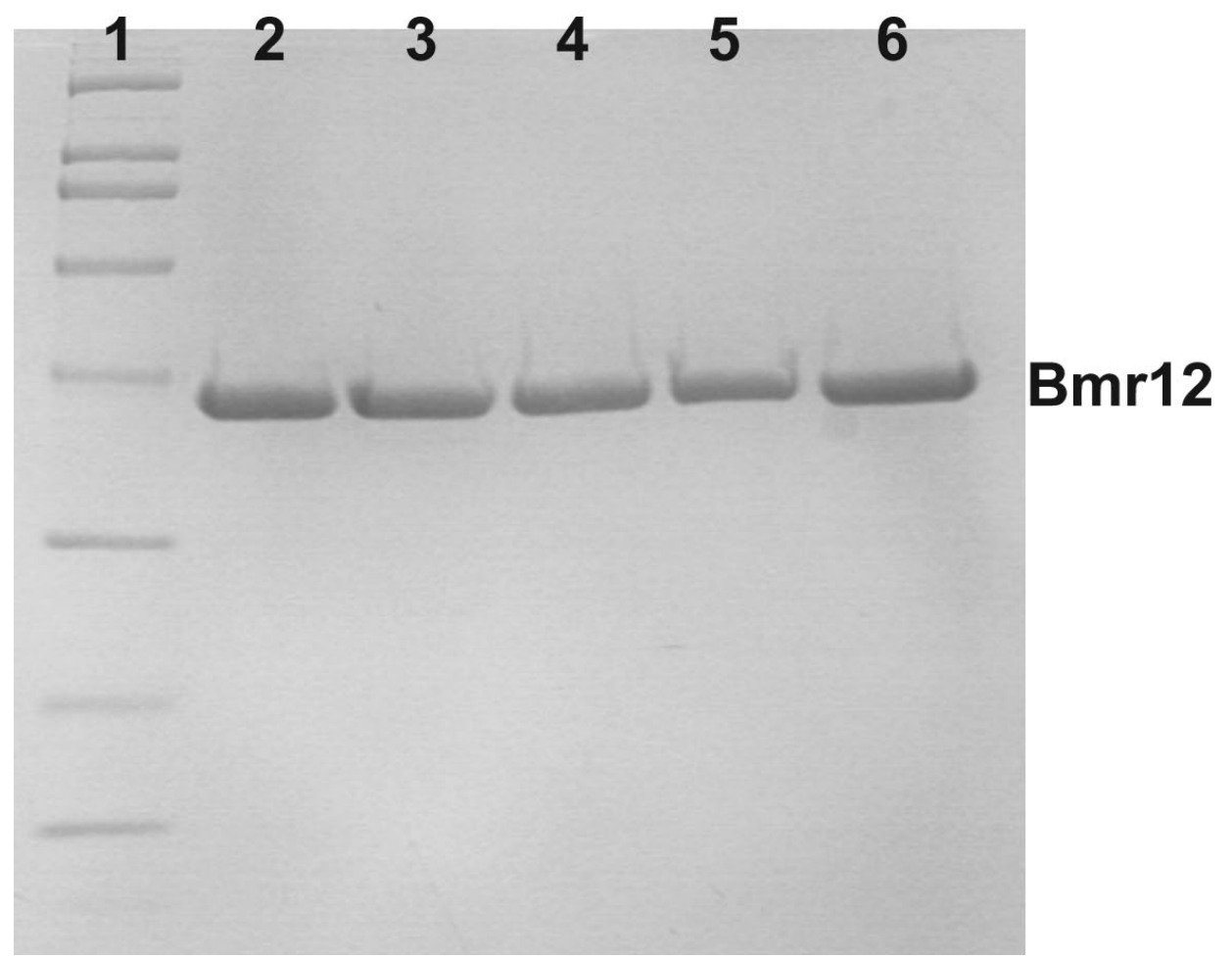


Supplementary Table 1. The effects of bmr12 mutants on flowering and plant height ${ }^{\mathrm{a}}$

\begin{tabular}{lllll}
\hline & $\begin{array}{l}\text { days to 50\% } \\
\text { anthesis }\end{array}$ & SEM & $\begin{array}{l}\text { height }(\mathrm{cm}) \\
\text { at maturity }\end{array}$ & SEM \\
\hline WT & $73.4 \mathrm{a}$ & 7.4 & $153 \mathrm{a}$ & 6.3 \\
bmr12-ref & $76.6 \mathrm{a}$ & 7.5 & $131 \mathrm{~b}$ & 6.3 \\
bmr12-30 & $86.6 \mathrm{~b}$ & 7.5 & $119 \mathrm{c}$ & 6.3 \\
bmr12-34 & $82.9 \mathrm{~b}$ & 7.5 & $133 \mathrm{~b}$ & 6.3 \\
bmr12-35 & $74.1 \mathrm{a}$ & 7.5 & $133 \mathrm{~b}$ & 6.3 \\
bmr12-820 & $89.4 \mathrm{~b}$ & 7.7 & $128 \mathrm{~b}$ & 6.5 \\
\hline
\end{tabular}

aMeans in rows with differing letters differ at $\mathrm{P}=0.05$ using an F-protected LSD. 


\title{
Erratum to: Identification and Characterization of Four Missense Mutations in Brown midrib12 (Bmr12), the Caffeic acid $O$-Methyltranferase (COMT) of Sorghum
}

\author{
Scott E. Sattler • Nathan A. Palmer • Ana Saballos • \\ Ann M. Greene - Zhanguo Xin • Gautam Sarath • \\ Wilfred Vermerris • Jeffrey F. Pedersen
}

Published online: 10 July 2012

(C) Springer Science+Business Media, LLC 2012

Erratum to: Bioenerg. Res.

DOI 10.1007/s12155-012-9197-z

The original version of this article unfortunately contained some mistakes. The name of the enzyme "Caffeic $O$-methyltransferase" should be read as "Caffeic acid $O$-Methyltranferase" throughout the paper, including the title.

On Table 2, the fifth column should have been captured as part of the sub-heading "Unpretreated". The corrected version is shown on the next page.

The online version of the original article can be found at http://dx.doi.org/ 10.1007/s12155-012-9197-z.

S. E. Sattler $(\varangle) \cdot$ N. A. Palmer · G. Sarath · J. F. Pedersen Grain Forage and Bioenergy Research Unit, USDA-ARS,

Lincoln, NE 68583, USA

e-mail: Scott.Sattler@ars.usda.gov

S. E. Sattler · N. A. Palmer · G. Sarath · J. F. Pedersen

Department of Agronomy and Horticulture,

University of Nebraska-Lincoln,

Lincoln, NE 68583, USA

A. Saballos $\cdot$ A. M. Greene $\cdot$ W. Vermerris

Agronomy Department and Genetics Institute,

University of Florida,

Gainesville, FL 32610, USA

Z. Xin

Plant Stress and Germplasm Development Unit, USDA-ARS,

Lubbock, TX 79415, USA 
Table 2 Variation in Klason lignin content and glucose yields obtained after enzymatic saccharification at $50{ }^{\circ} \mathrm{C}$ at $60 \mathrm{FPU} / \mathrm{g}$ cellulase of native (unpretreated) stover after 4, 20 , and $96 \mathrm{~h}$, and of pretreated stover after $24 \mathrm{~h}$

${ }^{a}$ Means in rows with different letters are statistically significant based on Tukey's HSD with an experiment-wise error rate of $0.05(n=9)$

\begin{tabular}{|c|c|c|c|c|c|}
\hline & \multirow{3}{*}{$\begin{array}{l}\text { Klason lignin }(\mathrm{mg} / \mathrm{g}) \\
\text { Mean (SD) }\end{array}$} & \multicolumn{4}{|c|}{ Glucose yield (mg/g stover) } \\
\hline & & \multicolumn{3}{|l|}{ Unpretreated } & \multirow{2}{*}{$\begin{array}{l}\text { Pretreated } \\
24 \mathrm{~h} \\
\text { Mean (SD) }\end{array}$} \\
\hline & & $\begin{array}{l}4 \mathrm{~h} \\
\text { Mean (SD) }\end{array}$ & $\begin{array}{l}20 \mathrm{~h} \\
\text { Mean (SD) }\end{array}$ & $\begin{array}{l}96 \mathrm{~h} \\
\text { Mean (SD) }\end{array}$ & \\
\hline WT BTx623 & $21.2(1.9) \mathrm{a}$ & $38(6) \mathrm{bc}$ & $54(5) d$ & $55(4) \mathrm{d}$ & $174(25) \mathrm{c}$ \\
\hline bmr12-ref & $17.1(0.8) \mathrm{cd}$ & $42(6) \mathrm{abc}$ & $62(5) \mathrm{cd}$ & $64(8) \mathrm{bcd}$ & $212(19) \mathrm{b}$ \\
\hline bmr12-30 & $18.4(0.9) \mathrm{bc}$ & 43 (13)abc & $64(7) \mathrm{bc}$ & $70(8) a b c$ & $230(27) a b$ \\
\hline bmr12-34 & $19.3(1.5) \mathrm{b}$ & $51(10) a b$ & $74(9) \mathrm{ab}$ & $74(9) \mathrm{ab}$ & $213(22) b$ \\
\hline bmr12-820 & $16.7(1.7) \mathrm{d}$ & $54(14) \mathrm{a}$ & $79(12) \mathrm{a}$ & $82(13) \mathrm{a}$ & $238(35) \mathrm{a}$ \\
\hline bmr12-35 & $19.6(0.5) \mathrm{ab}$ & $32(7) \mathrm{c}$ & $54(6) \mathrm{d}$ & $59(12) \mathrm{cd}$ & $178(12) \mathrm{c}$ \\
\hline HSD $(0.05)$ & 2.2 & 10 & 8.3 & 9.9 & 22 \\
\hline
\end{tabular}

